Article

\title{
The Paris Agreement: Consequences for the EU and Carbon Markets?
}

\author{
Steinar Andresen *, Jon Birger Skjærseth, Torbjørg Jevnaker and Jørgen Wettestad \\ The Fridtjof Nansen Institute, 1326 Lysaker, Norway; E-Mails: steinar.andresen@fni.no (S.A.), \\ jon.b.skjaerseth@fni.no (J.B.S.), tj@fni.no (T.J.), jorgen.wettestad@fni.no (J.W.) \\ * Corresponding author
}

Submitted: 20 April 2016 | Accepted: 13 July 2016 | Published: 8 September 2016

\begin{abstract}
Most observers argue that this agreement is a step in the right direction. However, we do not know how effective it will be in terms of reducing emissions. We therefore discuss its potential effectiveness regarding EU climate policies and carbon markets. We argue that the Paris Agreement may have a positive effect but uncertainties abound.
\end{abstract}

\section{Keywords}

carbon markets; effectiveness, EU; leadership; Paris Agreement

\section{Issue}

This article is part of the issue "Climate Governance and the Paris Agreement", edited by Jon Hovi and Tora Skodvin (University of Oslo, Norway).

(C) 2016 by the authors; licensee Cogitatio (Lisbon, Portugal). This article is licensed under a Creative Commons Attribution 4.0 International License (CC BY).

\section{Introduction}

The Paris Agreement attracted unprecedented media attention and was hailed by its creators as well as many observers as a watershed event, instrumental in contributing to a much-needed green global transition. Meeting in New York on April 22, the countries of the world demonstrated their overwhelming support for the Agreement-a strong signal of growing international commitment. It remains to be seen, however, whether these good intentions will translate into actual emissions reductions. Experiences from more than 25 years of UN climate diplomacy indicate that this is by no means self-evident: greenhouse gas (GHG) emissions today are more than $50 \%$ higher than when the UNFCCC was adopted in 1992 (Andresen, 2015). Will the Paris Agreement be able to break this trend?

That gives rise to the tricky question of how to measure the effects of international institutions-how and to what extent do they contribute to problemsolving effectiveness (Underdal, 2002)? Careful process-tracing is required, as behavior may be the result of various other factors than the regime in question. This methodological approach can be applied when an- alyzing the climate regime from its initiation until the present. But, with the ink hardly dry on the Paris Agreement (hereafter: PA), the best we can do now is to discuss its potential effectiveness.

Here we have chosen to discuss the potential effect on the EU and international carbon markets, with specific attention to the EU emissions trading system (EU ETS) as the biggest market so far. While the former case illustrates the impact on climate policy in general, the latter case shows how this plays out as to a specific policy-instrument. Our choice of the EU may be considered a "critical case", given its role as front-runner in the UN process. The PA can be expected to have effects on most states that had no previous emissions commitments. Will it also have effects on the most ambitious actor in the process, the EU? Regarding international carbon markets, the increased involvement and pressure on various business and industry actors have been hailed as major elements of the PA (Haas, 2015). Can we expect a further boost in carbon markets in its wake?

Potential effectiveness will depend on at least two conditions: a certain "distance" between PA requirements and the status quo; and influence through polit- 
ical, legal, and administrative/bureaucratic pathways (Cortell \& Davis, 1996). These pathways are by no means mutually exclusive and may very well co-exist. First, there is the legal pathway whereby international rules and procedures become incorporated in domestic law; this may affect the interactions between governmental and societal actors. Second, the political pathway directs attention to how government officials and societal actors can invoke international political declarations to further their own specific interests in domestic policy debates. Hence, international institutions or regimes may serve as "agents of internal realignments" (Levy, Young, \& Zurn, 1995, p. 307). In essence, international institutions might affect the alignment of domestic groups endeavoring to influence a government's behavior. Consequently, institutions can heighten state concern by magnifying public pressure in reluctant states (Haas, Keohane, \& Levy, 1993, p. 22). Similarly, governments may also be empowered to take action. The existence of international rules may be utilized for purposes of justifying own actions, or to question the legitimacy of the actions of others. In particular, governmental officials may cite international rules to legitimate unpopular decisions on stringent regulations. Finally, international institutional procedures may become enmeshed domestically through the standard operating procedures of bureaucratic agencies (Young, 1989, pp. 78-79). This third pathway-the "bureaucratic/administrative" pathway-indicates how international institutional procedures may affect domestic institutional procedures.

Key observers have given generally positive evaluations of the Paris Agreement, although they tend to underline different aspects. Bodansky (2015) stresses how the Agreement has injected new hope for the UN climate regime. Such increased legitimacy of the UN process may contribute to strengthen the legal pathway through rapid ratification. Haas (2015) argues that the PA represents a new political approach, one in which the focus of attention is private sector innovation and is subject to pressure from a constellation of other actors, including nongovernmental organizations (NGOs), social movements and the scientific community as well as the UN itself. If this rather optimistic scenario unfolds, it may contribute significantly to strengthening the political pathway. Victor (2015) strongly endorses the new hybrid architecture, arguing it will have a real impact on emissions, and that the PA will contribute to deeper commitments over time. However, he adds more detailed regulations are needed to secure an effective and dynamic review system that can serve to increase incentives for continued emissions reductions. van Assselt (2016) underlines the key role non-state actors may play in this regard. If this can be achieved, it will also help to strengthen the bureaucratic/administrative pathway by increasing nonstate actors' access to decision-making.

\section{The Paris Agreement: A Brief Evaluation}

Prior to the adoption of the Paris Agreement, the main legal instrument was the United Nations Framework Convention on Climate Change (UNFCCC) and the Kyoto Protocol with its two commitment periods. The UNFCCC represented a necessary start of the process through its framework approach. The Kyoto Protocol was an innovative instrument with novel characteristics, the flexible mechanisms. It also represented a step forward, with legally binding emission targets for the Annex 1 countries. At the time this made sense, as the countries of the Global North had main responsibility for creating the problem, and they were also the main emitters. However, since the Kyoto Protocol was adopted in 1997, emissions have been reduced in the North, while rising by some $160 \%$ in the South. Today, the industrialized countries with targets inscribed for the second commitment period account for only $15 \%$ of total global emissions (Andresen, 2015). For the UN climate regime to enhance its problem-solving effectiveness, the regulatory scope would have to be increased.

This was the background for radical new approach set forth in the 2009 Copenhagen Accord: a bottom-up approach based on a system of national pledges of nonbinding character without legal enforcement. Pledges were to be made by all countries, in contrast to the binary approach of the Kyoto Protocol. The Paris Agreement builds on and specifies this new approach. Considering the strong similarities between these two instruments, Bodansky (2015) has introduced the term "Copenparis". Why was the former regarded as a fiasco, while Paris has been considered a success? Observers have pointed to the stark difference in process between the two events (see Haas, 2015; Victor, 2015). In Copenhagen, the Danish leadership was considered weak and even counterproductive. In contrast, the French leadership is seen to have facilitated agreement though clever diplomacy before and during the negotiations. This helped to create broad ownership to the process and to build trust among parties. Bodansky (2015) agrees this may have had some positive effect. However, he claims, other factors are more important in explaining why a "Copenhagen look-alike treaty" was adopted in Paris. First, the main elements of the Accord had in practice been codified in the COPs between Copenhagen and Paris, so most parties had gradually realized this would be the main architecture of the new treaty. In this regard Oberthur and Groen (2016) add that no main actor wanted to take the blame for failure and that the US as well as China and lesser climate powers were aligned towards the goal of reaching agreement. Secondly, key emerging countries had de facto accepted that in practice the Kyoto track was a dead issue - unlike in Copenhagen, where they still anticipated a continuation of the Kyoto Protocol. Finally, expectations were far more realistic in Paris. In Copenhagen many still hoped for an agreement with 
strong legal bite. This was no longer the case. We can add a fourth reason: the vagueness of the Paris Agreement made it easy to accept. This is reflected by the fact that all major parties, from the USA to the Alliance of Small Island States (AOSIS), with widely different interests and preferences, embraced the PA as a success.

These factors explain why the Paris Agreement was widely accepted, but will this 'Copenhagen look-alike' set the world on a path to reduce emissions? That calls for a focus on aspects that set the Paris Agreement apart from the Copenhagen Accord. While the latter was a soft political document, the former is a treaty in the meaning of the Vienna Convention on the Law of Treaties. Legal treaties can be expected to have more significance for the behavior of their members than soft political documents, although this is a complex question (Skjærseth, Schram Stokke, \& Wettestad, 2006). However, the practical significance of the PA's legal force should not be exaggerated. For example the US administration firmly opposed being bound to the achievement of its declared target. Still, the PA is a treaty under international law and we argue that it is an advantage that the Paris Agreement is a legal treaty.

While the Copenhagen Accord had entailed an almost pure "bottom-up" approach, in Paris agreement was reached on a more hybrid architecture. The parties are required to provide information about their pledges to track progress as regards implementation. Of particular importance is that the parties are taking on $\mathrm{Na}$ tionally Determined Contributions (NDCs) when they ratify the PA. Furthermore it establishes a regular fiveyearly "stock-take" to be provided every five years from 2023 to be progressively more ambitious over time. This dynamic and transparent element is promising, but is also vulnerable, as much depends on the will and ability of countries to deliver on their pledges. Also, a soft (top-down) approach has been chosen, as the PA has weak compliance mechanisms and no sanctions. That makes it weaker than the Kyoto Protocol, but was probably necessary to get key actors on board.

While the PA copies the Copenhagen goal of not exceeding a temperature increase of $2^{\circ} \mathrm{C}$, it also adds the aspirational $1.5{ }^{\circ} \mathrm{C}$ target. As a point of departure, an ambitious goal is preferable to no goals or a goal than can be very easily reached. Ideally it may help members to the agreement to stretch further than they would otherwise do. However, it is important to have a match between the goal and the institutional underpinning necessary to reach the goal adopted. Judging from the pledges made so far, neither of these goals will be attained, so the Parties will have to expand their ambitions considerably in the future if the Paris Agreement is to live up to expectations.

\section{The EU: Before, in and after Paris}

Before Paris: Since the 1990s, the EU has aimed at showing leadership by example in the international climate regime. The credibility of this ambition has been strengthened by adding increasingly more ambitious targets and policies and actual results on the ground. In 2007 and 2008, the EU leaders agreed on climate and related energy targets and binding policies for 2020, including cutting GHG emissions by 20 percent by 2020 compared to 1990 levels. Targets and policies for 2020 spurred the first step towards a longterm strategy when, in 2009, the EU leaders agreed to support an EU goal of reducing GHG emissions between $80 \%$ and $95 \%$ by 2050 against 1990 levels (European Council, 2009).

The European Commission used the 2009 "decarbonizing" by 2050 agreement as a foundation for stepping up long-term climate strategies. In 2011, it issued a roadmap for moving towards a competitive lowcarbon economy by 2050 , showing that GHG emissions would have to be reduced by $40 \%$ by 2030 and $60 \%$ by 2040, compared to 1990 levels (European Commission, 2011). In October 2014, the 28 EU leaders apparently delivered on the low-carbon strategy by adopting a climate and energy policy framework for 2030, including a new goal of domestic GHG reductions of at least 40\% compared to 1990 (European Council, 2014). They also agreed to "revert to" the issue after the Paris Conference, indicating that the EU targets might be adjusted in light of the outcome. By 2015, total EU GHG emissions were already $23 \%$ below 1990 levels -which also reflected various factors not directly related to climate policy, such as the activity-dampening effects of the economic crisis.

Climate policies and achievements underpinned the leadership-by-example ambition when the EU prepared for the Paris Conference. The $40 \%$ by 2030 target served as the EU's proposed NDC for the upcoming Paris meeting. In September 2015, EU ministers adopted the EU's negotiating mandate that also included preferences for an ambitious, transparent, dynamic, and legally binding agreement (including the NDCs) based on science. For the EU, "science" means the 2007 fourth assessment report of the IPCC, which indicates that developed countries should reduce emissions by $80-95 \%$ by 2050 to limit global warming to $2^{\circ} \mathrm{C}$. For poor countries, financial support should be stepped up.

While EU climate ambitions may appear impressive, they mask significant political tension and differing interests within the EU. Poland and a group of Central and Eastern European countries dependent on domestically produced coal do not favor the EU's long-term climate ambitions. More concerned with energy security, they have been playing along for the time being as a result of political pressure, derogations, and financial support. Another line of diverging interests goes between the energy-intensive industries that argue for a level playing field between the EU and major competitors, and the electric power industry shielded from 
competition outside Europe (Skjærseth, Eikeland, Gulbranden, \& Jevnaker, 2016). It has also been argued that the EU's climate strategy does not add up to the EU's 2050 target (Dimantchev \& Schjølset, 2016), but relies on uncertain technological improvements and the progressive up-scaling of efforts after 2030.

In Paris: Internal political tensions represented a real risk of EU division during the Paris Conference. Poland had vetoed the 2050 strategy and opposed the EU's negotiating mandate for COP21, but became isolated after being granted concessions regarding some changes in wording that made no substantial difference (EurActive, 2015). Poland's new, climate-skeptical conservative government initially also threatened to torpedo COP21, but changed its stance conditional on an outcome that would protect the interests of the Polish economy (Politico, 2015). That meant protection of coal-nearly $90 \%$ of Poland's electricity is produced by mainly indigenous coal that feeds 53 coal-fired plants, with a dozen new ones expected to come online before 2020 (Skjærseth, 2014). Despite initial opposition, the EU managed to maintain considerable political unity throughout the Paris Conference, helping to build a "high-ambition coalition" that proved instrumental in achieving a dynamic agreement with all big emitters on board. Poland was pleased when references to "phasing out of fossil fuel subsidies" were deleted from the PA text (CAN Europe, 2015). The Paris Agreement became more ambitious than the EU position with its aspirational goal of limiting the temperature increase to $1.5^{\circ} \mathrm{C}$. The dynamic element was, as noted, adopted with the addition of a "global stocktaking" every five years from 2023 to consider progress in emissions reductions. The NDCs were not made binding, but the parties are legally obliged to pursue measures for meeting their contributions.

After Paris: The $1.5^{\circ} \mathrm{C}$ aspirational goal created a "distance" between the PA outcome and EU targets, policies, and position, which are based on the $2.0^{\circ} \mathrm{C}$ goal. This gap provides the PA with the potential to affect EU climate policy. Politically, the EU institutions responded immediately and enthusiastically to the Paris outcome. European Commission President Juncker described the deal as "robust" and as a success for the EU. EU Climate and Energy Commissioner Cañete followed up by praising the EU efforts to build a highambition alliance, characterizing the deal as a major win for Europe (European Commission, 2015a). The European Parliament delegation to COP21 called it an "unprecedented breakthrough in the fight against climate change" and emphasized the need to follow up the $1.5{ }^{\circ} \mathrm{C}$ goal by concrete policies (European Parliament, 2015). Non-state actors with varying climate-policy interests were supportive as well. BusinessEurope, with national business federation members across Europe, described the deal as a "major step forward," but voiced concern that the agreement did not solve the is- sue of competitiveness for European industries in highly competitive global markets (BusinessEurope, 2016). The electric power industry, represented by EURELECTRIC, firmly welcomed the outcome, describing the deal as a "major landmark" (Eurelectric, 2015). The European oil industry, and one of the least climateenthusiastic energy-intensive industries - steelwelcomed the deal as well, but stressed the need for a strategy to provide a competitive level playing field and protect Europe's industries from carbon leakage (Eurofer, 2015; FuelsEurope, 2015). In their response, Europe's largest green NGO coalition on climate and energy issues-Climate Action Network-listed the goods and not-so-goods, including the $1.5{ }^{\circ} \mathrm{C}$ target and the lack of binding country contributions, respectively (CAN Europe, 2015).

The EU would "revert to" the 2030 framework after Paris. The positive responses to the dynamic long-term PA were used by "green" groups to argue for tighter EU targets and policies. In March 2016, the Commission responded formally with its Communication "The Road from Paris" (European Commission, 2016). The key message disappointed the green groups-the 2020 and 2030 targets were to remain unchanged. The EU would participate in the first global stocktaking in 2023 and would consider more ambitious action beyond 2030 . Priority number one in following up the PA would be to adopt binding policies on climate change (inclusion of Land Use, Land Use Change and Forestry, revision of the EU Emissions Trading System and emission reduction in the non-trading sectors), renewables and energy efficiency-policies planned before the PA to fill the 2030 framework with specific legislation. Further, the policy implications of the $1.5{ }^{\circ} \mathrm{C}$ goal must be addressed, and the EU would provide input to a special IPCC report on this issue in 2018.

The member states discussed the Communication at their Environment Council meeting the same month. The Communication was broadly welcomed, although some ministers advocated higher ambitions (Environment Council, 2016). Many ministers highlighted the need to maintain the Paris momentum for adopting new 2030 policies and implementation. The subsequent EU leaders' meeting became overshadowed by the migration crisis, but there was broad support for the Commission's Communication (European Council, 2016). In summary, the main political impact of the PA thus far seems to be to justify EU climate policy and to legitimize the positions of the "frontrunners." This will help to delegitimize opposition and make it more difficult for countries like Poland to question EU climate policy.

As regards the legal aspects, the EU has signed the $\mathrm{PA}$, and intends to ratify the treaty "as soon as possible" (European Commission, 2016, p. 4; European Council, 2016). Combined with the legally binding obligation to pursue domestic measures, ratification of the PA will probably put pressure on "laggards" for swift adoption 
of binding policies to deliver on the 2030 target. To ensure legitimacy, EU climate policies will need broad support, beyond qualified majority. The EU leaders have agreed to provide strategic orientation with respect to consensus on the ETS and non-ETS (European Council, 2014). The main bureaucratic/administrative effect of the PA is likely to be its dynamic nature and global stocktaking mechanism. Although this mechanism was strongly favored by the EU, it will keep discussions warm concerning the match between current and planned policies and the EU's 2050 "decarbonization" target.

In conclusion, no EU political actor thus far has used the PA to argue for lower levels of ambition: indeed, the EU institutions, member states, industries, and the green movement have all argued for keeping or raising the level of short- and long-term ambitions. The $1.5^{\circ} \mathrm{C}$ goal and the dynamic nature of the PA will trigger a follow-up process that may lead to higher ambitions beyond 2030, particularly since uncertainty prevails on whether EU targets and policies add up to the EU's 2050 goal. The combination of political, legal, and bureaucratic/administrative consequences of the PA will increase the pressure on "laggards" within the EU to deliver on and support the $40 \%$ reduction target by 2030 and beyond. Carbon capture and storage (CCS), a key political solution for coal-based member states like Poland and a technological precondition for "decarbonization", has failed across Europe, so the EU will need the PA to legitimate future unpopular decisions on stringent regulation (Skjærseth et al., 2016). The PA may contribute to keep climate at the agenda when the EU is dealing with a number of (other) internal and external crisis. However, it is far too early to pronounce on the actual longer-term impact of the Paris Agreement on the EU.

\section{Paris and Carbon Markets: Positive Implications- But Help for a Struggling EU ETS?}

The EU ETS is the world's largest carbon market to date, and has been in place for more than a decade. However, it has struggled with a carbon price that has been both volatile and too low to provide forceful incentives to a low-carbon transformation. 2015 saw the adoption of important structural reform of the EU ETS and of a global climate agreement. Thus, the scene was set for a positive development of carbon trading in general and within the EU in particular. Nevertheless, the European carbon price has since dropped. Although additional tightening of the EU ETS has been suggested, this now seems to be a long shot. Having fought heavily to get the structural reform adopted last year (Wettestad \& Jevnaker, 2016), the interest in reopening that can of worms is low.

Moreover, after years of weak economic growth, the EU has not been willing to strengthen its overall climate targets in light of the PA, including the $1.5^{\circ} \mathrm{C}$ ambition (see previous section). Despite the advent of a global climate agreement, the EU still regards carbon leakage a major issue. Shielding EU industries from climate policy in order to preserve their global competitiveness remains important, indicating a "wait and see" attitude towards the bottom-up regime put in place by the PA. How could this be? In this section, we explore the interaction between the EU ETS reform process and the global climate regime along the legal, political and the administrative/bureaucratic pathways.

The Paris Agreement includes elements of relevance for carbon markets, as well as a review process that is intended to strengthen regional and domestic climate policy. The Paris meeting was not expected to give anything to carbon markets, but the implicit and explicit reference to elements associated with carbon markets gave rise to optimistic assessments as to the future of carbon trading. The term "market" was deemed too controversial to be mentioned explicitly in the Agreement itself (except when referring to nonmarket approaches), although the term "carbon pricing" appears in relation to non-party stakeholders in a COP decision accompanying the agreement, where it is referred to as a tool for incentivizing emission reduction along with domestic policies. Nevertheless, language relevant to the development of carbon markets was included in the Paris Agreement. Here, cooperation among countries in achieving their national climate policies (NDCs) was acknowledged: countries could cooperate on implementation by trading "internationally transferred mitigation outcomes" (ITMOs, Art. 6.2). Moreover, a mechanism for sustainable development would be set up (Art. 6.4), building on previous global offsetting mechanisms (Clean Development Mechanism and Joint Implementation), with the specific design to be decided at subsequent meetings. Beyond this, the PA included provisions for periodical review of national climate policies that were to be at least as ambitious as the previous version.

What, then, will the PA entail for the subsequent development of carbon markets? In the following we will concentrate on its impact on the EU ETS, but let us first note a few points as to carbon markets more generally. This includes both the emergence of carbon markets individually and "collectively", i.e. the processes of linking them. The legal pathway is weak as to effects on individual carbon markets, although the PA offers language referring to carbon markets. There is nothing in the PA that requires countries to adopt and implement legislation for a carbon market. Thus, carbon markets will probably continue to emerge in fragmented and piecemeal ways, as in the past. However, the turn to emissions trading in China, today the world's biggest emitter, is important, and could accelerate ETS adoption rates globally. China has already launched plans for a national ETS. Moreover, many countries' INDCs included plans for carbon trading. Together these two factors related to the legal pathway 
from the PA-being voluntary and bottom-up rather than top-down and binding-could see enhanced cooperation on this climate policy instrument.

Additional support could come from a follow-up process from the PA on providing common guidance on carbon accounting rules. This is essential for the basic trust of data, and thus for linking processes to work. Although linking could offer cost-efficient emission reduction, there is no 1-to-1 relationship between functionality and linking. In the past, prior cooperation between regions, countries, or sub-national entities has been important for linking emissions trading schemes, and differences in the design of carbon markets can pose challenges unless there is clear political will to make adjustments (Jevnaker \& Wettestad, 2016). The legal pathway might also be activated where the PA is used by actors at the domestic or transnational arena in order to push for (more) ambitious caps and wellfunctioning price management mechanisms. Finally, this might coincide with the administrative/bureaucratic pathway, as the five-year cycle of reviews offers opportunities for actors to utilize this window of opportunity for placing carbon-market issues on the political agenda.

Turning to the EU carbon market, the PA was welcomed by proponents of a stronger EU ETS. Earlier the same year, the EU had finally agreed on a structural reform of its ETS in order to deal with a structural surplus that threatened to undermine the system as well as long-term climate targets. From 2019 onwards, a "market stability reserve" (MSR) would regulate supply by automatically withdrawing or releasing allowances should the total amount of allowances in circulation cross upper or lower thresholds. The road towards reform had been paved with daggers, first with controversy as to whether or not to intervene in the carbon market at all, and then on how to intervene.

It took a heavy load to turn this around: The German election in 2013 resulted in a new coalition government accompanied by structural changes to the energy and environmental ministries. This moved Germany from being reluctant to supportive of carbon market reform. Moreover, bargaining deals in the (European) Council and in the European Parliament were enabled in part because proposals were recalibrated to make them politically feasible, and in part due to concessions given to Central and Eastern member-states, but also due to the display of power, with West European member states overruling Poland and some other CEECs, through majority voting in the final MSR rounds. More generally, the reform process was facilitated by European Council conclusions on the 2030 climate and energy policy, in preparation for the Paris climate summit (Wettestad \& Jevnaker, 2016).

As regards the international dimension, EU interest in exercising international climate leadership had pushed EU-internal policy development ahead of the international climate summit in Copenhagen in 2009
(Boasson \& Wettestad, 2013). However, this seemed to figure less prominently-and certainly in different manner-prior to Paris. Worried about meager economic development after the financial crisis, with parts of Southern Europe still struggling, the EU was particularly concerned with economic competitiveness and vulnerability, making it more inward-looking. The low hopes of achieving a binding climate agreement in Paris meant that the pull from the external context in the form of global climate negotiations was clearly less than in 2008 , although it was not entirely absent (Wettestad \& Jevnaker, 2016).

Most observers expected that the adoption of the MSR would mark a turning point for an ETS in headwind since 2010. After meagre outlooks for the ETS price for several years, the carbon price now started climbing, slowly. More importantly, long-term expectations to the carbon price seemed likely to offer incentives to changes in behavior (fuel-switching) with anticipated levels of around $€ 30-40$ by 2030 (for an overview of the response to the MSR, see Wettestad \& Jevnaker, 2016). As mentioned above, the PA was seen as offering further support. Nevertheless, 2016 saw the return of a gloomy outlook. The carbon price dropped from just above $€ 8$ euro to $€ 5-6$, settling at around $€ 5$. Price estimates for 2030 also dropped significantly. Reacting to the low price, in March 2016 France proposed introducing a price corridor to the ETS, whereby allowances would be placed in the MSR if the price proved to be too low, and released if too high. This was designed to avoid the spread of national measures like the UK carbon-price floor. The Environment Ministry in the key ETS country Germany responded by stating that it was open to discussion of further reform options, but that, rather than a price-based regulation (as proposed by France), it preferred to keep the quantitative-based approach. Other tightening options, such as abolishing allowance banking between phases and a further tightening of the MSR parameters, have been put forward (see Carbon Pulse, 2016).

Thus, in the aftermath of PA, there were calls for increasing ambitiousness of both the overall EU climate target as well at the level of a cornerstone climate policy instrument. The former was related to the PA (and was rejected, see previous section), while the latter came as a response to a price drop. A possible strategy would be to attach such efforts to ongoing ETS reform discussions that were launched in mid-2015 following the adoption of the MSR (European Commission, 2015b). Up until mid-2016 (a decision is expected in early 2017), the debate among policymakers and stakeholders had centered on carbon leakage and support for low-carbon R\&D-aspects related to the cap had already been decided in practice by the European Council in October 2014 (Wettestad \& Jevnaker, 2016). Thus, the ongoing ETS discussions seemed to proceed unaffected by the PA. Instead, actors jumped on the 
price drop to justify further tightening of the system. However, the timing is complicated, as the EU has just concluded a heated and complicated process that ended in the adoption of the MSR. Central Commission officials including Climate and Energy Commissioner Cañete, have signaled disapproval of new tightening measures before the MSR has started to work. Moreover, the interest in shielding and supporting European businesses has remained in place and weigh heavy in current discussions, seemingly unaffected by the advent of a global climate agreement. Thus, neither the legal nor the political pathway have turned out to be important so far, as is the case for the bureaucratic/administrative pathway: follow-up procedures from the PA have not been connected to the ongoing discussion of ETS reform, which is likely to have been concluded by the time that the EU starts preparing for the review.

Could the PA become more important for ETS reform in the future? Without mandatory implementation of a given instrument, the legal pathway seems less relevant for this particular process. As to the bureaucratic/administrative pathway, entering the PA review cycle might affect future ETS discussions, and the MSR review in 2023 could follow up on PA deliverables due the same year. This is related to the political pathway, which for the interaction between the PA and the EU ETS appears most interesting, although requires support from actors within all three EU institutions. Moreover, in light of the diverging views of climate policy in general among member-states (Poland being partly compensated, partly overrun by Germany in the MSR process), strategic use of the PA to garner support for ETS reform across the board might be counter-productive, especially before having concrete evidence of comparable climate efforts emerging outside the EU. As such, successful Chinese carbon trading might trigger an interesting dynamic also inside the EU. As things stand now, however, the case of the EU ETS shows that it will be challenging to use the PA in internal processes and that hopes in this regard should be realistic and moderate.

\section{Concluding Comments}

Most observers agree that the PA is a step in the right direction in the process towards a new approach for dealing with the challenge of climate change, but the overall significance of this agreement in a problemsolving perspective is unknown. We have therefore focused on the potential impact of the PA-on the EU and carbon markets. We concluded that the dynamic structure of the agreement may trigger a follow-up process in the EU that could lead to greater ambitions beyond 2030 . The combined impact through the political, legal and bureaucratic/administrative pathways connecting the PA to the EU may also increase pressure on laggards within the EU. The agreement did not create a new global trading regime but it could create some momentum for actors favoring this instrument. Regarding the EU ETS, the world's largest carbon market, the political pathway is of greatest interest for the prospects of further tightening of the system and boosting the carbon price. Still, it will be challenging to use the PA in these internal processes and hopes in this regard should therefore be modest.

However important EU climate polices and carbon markets are for future international climate policies, the main challenges are elsewhere, primarily in developing countries. As these countries have previously had no "hard" commitments we believe the PA is an important step in bringing these countries on board. Equally important, the Paris Agreement contributed to restore the reputation of the UN as a major instrument in bringing this process forward. Still, it is important to realize that this avenue is one among many in the increasingly complex nature of the overall climate regime. However, the PA is important in this broader context as it focuses strongly on the importance of including non-state actors, not the least business and industry, into the process. In order to realize the high ambitions of the Paris Agreement non-state actors as well as states have to demonstrate a political will to deal with the problem that has so far been absent. Whether this can be realized remains to be seen, but with the global framework in place the ball is squarely passed back to them.

\section{Conflict of Interests}

The authors declare no conflict of interests.

\section{References}

Andresen, S. (2015). Effectiveness. In P. Pattberg \& F. Zelli (Eds.), Encyclopedia of global environmental governance (pp. 441-447). Cheltenham: Edward Elgar.

Boasson, E. L., \& Wettestad, J. (2013). EU climate policy: Industry, policy interaction and external environment. Farnham: Ashgate.

Bodansky, D. (2015, December 15). Reflections on the Paris Conference. Opinio Juris. Retrieved from http:// opiniojuris.org/2015/12/15/reflections-on-the-parisconference

BusinessEurope. (2016). Views on the impact of the Paris agreement on the 2030 framework for climate and energy policies. Retrieved from https://www.busi nesseurope.eu/publications/businesseurope-viewsimpact-paris-agreement-2030-framework-climateand-energy-policies

CAN Europe. (2015). CAN Europe's assessment of the Paris Agreement. Retrieved from http://www.caneu rope.org/policy-work-articles/272-un-climate-negoti ations/943-our-assessment-of-the-paris-agreement

Carbon Pulse. (2016). Comment: Resuscitating the EU ETS. Retrieved from http://carbon-pulse.com/17489 
Cortell, A.P., \& Davis, J.W. Jr. (1996). Do international institutions matter? The domestic importance of international rules and norms. International Studies Quarterly, 40, 451-478.

Dimantchev, E., \& Schjølset, S. (2016). EU climate ambition: Falling short on long-term targets? Oslo: Thomson Reuters Point Carbon.

Environmental Council. (2016). Outcome of the $3452^{\text {nd }}$ Environment Council meeting, March 4, 2016. Retrieved from http://www.consilium.europa.eu/en/ meetings/env/2016/03/04

EurActive. (2015, September 18). Ministers unite on mandate for Paris climate talks. Retrieved from https://www.euractiv.com/section/energy/news/mi nisters-unite-on-mandate-for-paris-climate-talks/

Eurelectric. (2015, December 14). Eurelectric hails successful outcome from Paris Climate Change Conference. Retrieved from http://www.eurelectric.org/ news/2015/eurelectric-hails-successful-outcomefrom-paris-climate-change-conference

Eurofer. (2015). Position paper: Eurofer welcomed the global agreement. Brussels: Eurofer.

European Commission. (2011). A roadmap for moving to a competitive low carbon economy in 2050. Brussels: European Commission.

European Commission. (2015a). Historic deal in Paris: EU leads global efforts. European Commission. Retrieved from http://ec.europa.eu/clima/news/articles/news _2015121201_en.htm

European Commission. (2015b). Proposal for a directive of the European parliament and of the Council amending directive 2003/87/EC to enhance costeffective emission reductions and low-carbon investments. Brussels: European Commission.

European Commission. (2016). The road from Paris. Brussels: European Commission.

European Council. (2009, December 1). Presidency conclusions from European Council, October 29 and 30, 2009. Brussels: European Council.

European Council. (2014, October 24). Presidency conclusions from European Council, October 23 and 24, 2014. Brussels: European Council.

European Council. (2016, March 18). European Council conclusions, March 17 and 18. Brussels: European Council.

FuelsEurope. (2015, December 18). COP21-EU negotiators should be proud of what has been achieved in Paris, and should renew their efforts to ensure that it results in effective global action. Retrieved from https://www.fuelseurope.eu/mediaroom/61/54/CO P21-EU-negotiators-should-be-proud-of-what-has-be en-achieved-in-Paris-and-should-renew-their-effortsto-ensure-that-it-results-in-effective-global-action

Haas, P. (2015, December 17). The day after Paris: politicians hand the baton to green industries. The Conversation. Retrieved from http://theconversation. com/the-day-after-paris-politicians-hand-the-baton- to-green-industries-51787

Haas, P. M., Keohane, R. O., \& Levy, M. A. (Eds.). (1993). Institutions for the Earth: Sources of effective international environmental protection. Cambridge, MA: MIT Press.

Jevnaker, T., \& Wettestad, J. (2016). Linked carbon markets: Silver bullet, or castle in the air? Climate Law, 6(1-2), 142-151.

Levy, M. A, Young O. R., \& Zurn, M. (1995). The study of international regimes. European Journal of International Relations, 1(3), 267-330.

Oberthur, S., \& Groen, L. (2016, May 11-13). Explaining success in international negotiations: The EU and the Paris Agreement on Climate Change. Paper presented at the EU in International Affairs Conference, Brussels, Belgium.

European Parliament. (2015). COP21 Paris agreement: MEPs hail a new beginning for climate action [Press release]. Retrieved from http://www.europarl.euro pa.eu/news/es/news-room/20151212IPR07301/COP 21-Paris-agreement-MEPs-hail-a-new-beginning-forclimate-action

Politico. (2015, November 30). Poland takes a tough line ahead of COP21. Politico. Retrieved from http:// www.politico.eu/article/poland-tough-line-cop21paris-climate-summit

Skjærseth, J. B. (2014). Implementing EU climate and energy policies in Poland: From Europeanization to Polonization? (FNI Report No. 8/2014). Lysaker, Norway: Fridtjof Nansen Institute.

Skjærseth, J. B., Eikeland, P. O., Gulbrandsen, L. H., \& Jevnaker, T. (2016). Linking EU climate and energy policies: decision-making, implementation and reform. Cheltenham: Edward Elgar.

Skjærseth, J. B., Schram Stokke, O., \& Wettestad, J. (2006). Soft law, hard law and effective implementation of environmental norms. Global Environmental Politics, 6(3), 104-121.

Underdal, A. (2002). One question, two answers. In E. Miles, A. Underdal, S. Andresen, J. Wettestad, J. B. Skjærseth \& E. Carlin (Ed.), Environmental regime effectiveness (pp. 3-47). Cambridge, MA: MIT Press.

van Asselt, H. (2016). The role of non-state actors in reviewing ambition, implementation and compliance under the Paris Agreement. Climate Law, 6, 91-108.

Victor, D. (2015, December 15). Why Paris worked: A different approach to climate diplomacy. Yale Environment 360. Retrieved from http://e360.yale.edu/ feature/why_paris_worked_a_different_approach_ to_climate_diplomacy/2940/

Wettestad, J., \& Jevnaker, T. (2016). Rescuing EU emissions trading-The climate policy flagship. Basingstoke: Palgrave Pivot.

Young, O. R. (1989). International cooperation: Building regimes for natural resources and the environment. Ithaca, NY: Cornell University Press. 


\section{About the Authors}

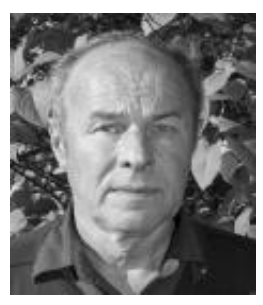

Steinar Andresen is a research professor at the Fridtjof Nansen Institute in Norway. He has also been a professor at the Department of Political Science and an adjunct professor at the Faculty of law, both University of Oslo. He has also been affiliated with various international institutions as a guest researcher. He has published extensively internationally, mostly on international environmental governance.

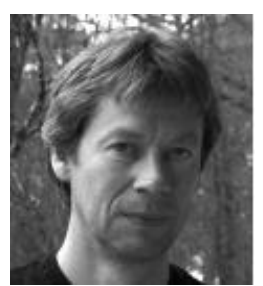

Jon Birger Skjærseth is a research professor at the Fridtjof Nansen Institute. His research interest focuses on various environmental challenges, including climate and energy policies and strategies at the corporate, national, EU and international levels. He has published extensively in these fields, including a number of books.

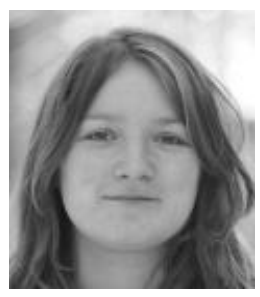

Torbjørg Jevnaker is a research fellow at the Fridtjof Nansen Institute and PhD candidate at the Department of Political Science, University of Oslo. Her research interests include climate and energy market policy within the EU, organization studies and public administration.

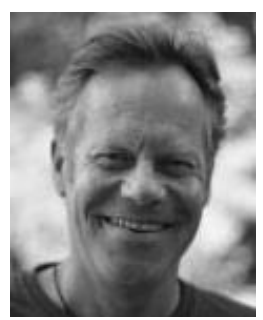

Jørgen Wettestad is a research professor at the Fridtjof Nansen Institute. He has published several books and numerous articles on international and EU environmental policy with particular attention to emission trading. His most recent book (together with Torbjørg Jevnaker) is Rescuing EU Emission Trading: The Climate Policy Flagship (Palgrave, 2016). 